\title{
Determinative Factors of Students' Reading Interest at Community Education Units in Bandung
}

\author{
Rita Kustari Koesma, Achmad Hufad, Ihat Hatimah, Ace Suryadi, Dadang Yunus \\ Lutfiansyah
}

\begin{abstract}
This research based on Indonesian Act about National Education System, UU RI No.20 Tahun 2003 article 26 section (4): non-formal education units consist of courses, training organizations, learning communities, community learning centre, majelis taklim, and so forth. The general objective of this research was to observe the factors determining the students' reading interest at community education units in Bandung. Quantitative and qualitive approach or mix method was applied to this research. Qualitative approach was used to describe the empiric condition and the program implementation. The quantitative approach was applied to find out the determinative factors of students' reading interest. The data were collected from observation, interview, questionnaire, and documentation study which were applied to 267 data sources. The result showed that some units have used computer-based system, such as SLIMS, INLIST, OPAC, blog, and website. The implementation of the system increased the numbers of visitor. The determinative factors affecting the reading interest are divided into two, which are internal factor (motivation, interest) and internal factor (jobs, group, environment, and interpersonal relationship). Similar jobs create similar goals, so the learning community is created.
\end{abstract}

Index Terms: community education unit, reading interest, determinative factor.

\section{INTRODUCTION}

Nowadays, education is very important because it is the root of the civilization. Education is the basic need to face the challenge in life. Education can be reached in many ways. One of them is library which is a place to get much information, knowledge, and other benefit. According to Paulina Mickiewicz (2016, p. 239), "libraries are no longer 'just libraries,' but a hybrid of different specializations and services that have come together to create a new public

Revised Manuscript Received on September 22, 2019.

Rita Kustari Koesma, Community Education Department, Universitas Pendidikan Indonesia, Bandung, Indonesia. Email: ritakoesma@student.upi.edu,

Achmad Hufad, Community Education Department, Universitas Pendidikan Indonesia, Bandung, Indonesia. Email: achmadhufad@upi.edu

Ihat Hatimah, Community Education Department, Universitas Pendidikan Indonesia, Bandung, Indonesia. Email: ihat.hatimah@upi.edu

Ace Suryadi, Community Education Department, Universitas Pendidikan Indonesia, Bandung, Indonesia. Email: acesuryadi@upi.edu

Dadang Yunus Lutfiansyah, Community Education Department, Universitas Pendidikan Indonesia, Bandung, Indonesia. Email: dadangyunus@upi.edu space." Globalization demands changes of paradigm from the competiton in term of material to the competition based on knowledge. This paradigm required the institutions or organizations to produce high-quality human resources and to be comparatively and competitively superior. So that, Indonesian Act about national education system UU RI No. 20 Tahun 2003 annuciated the need of education programs to improve the life quality and the dignity of Indonesian people. To improve the quality of human resources, education must be improved as well. Martínez-Guido, S. I., González-Campos, J. B., \& Ponce-Ortega, J. M. (2019) stated that the focus of human development index is to measure average achievement in human development in a society. This tool is a statistic composite index of life expectancy, school enrolment and per capita income indicators, and provide a general view of societies and their quality of life. Essentially, education is conscious and organized effort to create learning scene and learning process which support the students to develop their potential in spiritual, self-control, personality, intelligence, noble character, and required skill for themselves, society, and their country.

Indonesia not only has the formal education as their education system. Non-formal education or community education is one of the education system ouside the formal eduation. This based on UU No. 20 Tahun 2003 about national education system which is "Education is divided into formal education, non-formal education, and informal education that complete each other." Formal education is generally conducted at schools. It presents clear continuous learning stages, starting from primary education to higher education. Non-formal education, in the other hand, is carried on outside the formal system. It was also organized and systematic. Non-formal education can be found at early-childhood education programs and basic education programs, for instance TPA (Quran literacy) at the mosque or Sunday school at the church. Moreover, it also consists of some courses, such as music classes, tutoring, and others. Informal education is defined as the education from daily life, environment, and family. The examples are homeschooling and community learning centre. 
Indonesian has realized the importance of education to unlearn the backwardness and to keep improving. Education cannot be separated from learning activities which include reading activity. So, reading is one of the ways to educate individual, society, and the nation.

In 1972, UNESCO prioritized the incrase of reading interest. A program called Books for All was launched to increase the reading interest of the people in the world. In Indonesia, the president, Soeharto, declared Hari Kunjungan Perpustakaan (Library Visiting Day) in 1996. President Megawati carried out Gerakan Nasional Gemar Membaca (National movement to persuade people to read) in 2002. In Mei 2007, Vice president Jusuf Kalla officially announced the electronic mobile library service by Indonesian National Library. However, these movement had not showed the expected result.

Based on some reports, Indonesian reading interest level was still low compared to the some ASEAN countries. UNDP report about Human Development Index based on the illiteracy level in 2003 showed that Indonesia was in the $112^{\text {th }}$ out of 174 countries. In addition, based on "Most Littered Nation in the World" by Central Connecticut State Univesity in 2016, Indonesian reading interest was in the $60^{\text {th }}$ out of 61 countries. Indonesian children's reading literacy is lower than the other developing countries. In 1992, International Association for Evaluation of Educational (IEA) conducted a study in reading literacy of primary school students. The result showed that Indonesia was in the $29^{\text {th }}$ of 30 countries, one level above Venezuela which is in the $30^{\text {th }}$.

The previous data was relevant to the study result of Vincent Greannary quoted by World Bank in an education report entitled "Education in Indonesia from Cricis to Recovery" in 1998. The result showed the level of reading literacy of the $6^{\text {th }}$ grade Indonesian students was the lowest with 51.7 below the other countries, such as Philiphine with 52.6, Thailand with 65.1, Singapore with 74.0 and Hongkong which was scored 75.5.

Some reseaches showed that the higher the interest the higher the productivity of the learning activities and vice versa. It can be concluded that a program for adult learners will be successful if the program is able to accommodate the reading interest of learners in order to fulfill the learning need. Benes (in Hubackova, S., \& Semradova, I., 2014) stated that "Decisive-making is the fact that the adults do not educate themselves with a view to satisfy their own knowledge progress but with a view to their needs for solving their own concrete problems". To increase the reading interest starts from motivation to read. According to $\mathrm{Mc}$ Donald in Sardiman (2008, pg. 71), motivation is the changing of energy from the inside signed by "feeling" and initiated by goal. In conclusion, Mc Donald described that individual would be motivated if the things had benefit for themselves.

The basic obstacles in improving the quality of human resouces was the low interest in reading. Whereas, the next generation have to prepare themselves to deal with the competitive world. One way that can be done is to provide understanding to parents to improve the environment that supports literacy. Pezoa, J. P., Mendive, S., \& Strasser, K. (2019) suggested that "interventions designed to improve the home literacy environment could be attained through improving parents' perceptions of children's reading interest rather than seeking only to change parents' practices directly". The next generation, which is the youth, have to prepare themselves to face the new era where the competitiveness becomes the priority in all field.

Learning activity cannot be separated from reading activity. Moreover, Harry Maddozx (1964) suggested that reading is the most important skill in the study. It showed how necessary reading is as Ralph C. Staigner (1973) said that reading has frequently been regarded as a tool facilitating many other types of learning. Reading habit will be improve if it is supported by good language ability or reading skill as well as the availiability of books.

In contrary, good reading skill was unbeneficially wasted if there are only limited numbers of books. In the Indonesia Act UU No. 43 Tahun 2003 about Library article 48 section 1 , it said that the reading culture can be started from family, education units, and society.

Based on the previous explanation, the researcher conducted a study about the determinative factors affecting students' reading interest at community education units in Bandung.

\section{LITERATURE REVIEW}

Based on the review of some references and points of views, literacy can be defined as a set of ability and skill in reading, writing, communicating, calculating, and problem solving in the certain level which is required in daily life.

Literacy was identical with reading and writing. However, Declaration of Prague in 2003 suggested that literacy also encompassed the way people communicate in the community. Literacy practically means social relation related to knowledge, language, and culture (UNESCO, 2003).

One way to improve literacy was reading books. Unfortunately, reading did not seems as Indonesian culture proved by the low of reading interest. It resulted in the literacy level which was also undeniably low. There were some things caused the low of reading interest, which were 1) the low of reading interest of the teachers; 2) are unaccessiblity of interesting books; 3) unproper library; 4) the limited numbers of books; 5) learning activities was not literacy based.

In 1960s, the notion of literacy developed not only related to language, but also developed into functional concept which was related to some fuctions and life skills (Sofia Valdivielso Gomez, 2008).

The term of literacy was defined as a set of skills in processing the information. It was more complicated than the ability to analyse and comprehend the reading and writing. In the other words, literacy was not only about reading and writing, but also about other field, for instance economy, and Engin

? IJTRE 
math, science, social, environment, finance and moral literacy.

Indonesian children's reading literacy was lower than the other developing countries. In 1992, International Association for Evaluation of Educational (IEA) conducted a study in reading literacy of primary school students. The result showed that Indonesia was in the $29^{\text {th }}$ of 30 countries, one level above Venezuela which is in the $30^{\text {th }}$.

The previous data is relevant to the study result of Vincent Greannary quoted by World Bank in an education report entitled "Education in Indonesia from Cricis to Recovery" in 1998. The result showed the level of reading literacy of the $6^{\text {th }}$ grade Indonean students was the lowest with 51.7 below the other countries, such as Philiphine with 52.6, Thailand with 65.1, Singapore with 74.0 and Hongkong which was scored 75.5 .

UNDP report about Human Development Index based on the illiteracy level in 2003 showed that Indonesia was in the $112^{\text {th }}$ out of 174 countries, while Vietnam was in the $109^{\text {th }}$. In spite of that, Vietnam believed that they could be improved by developing their "human" (Baderi, 2005).

Statistics Indonesia (BPS) in 2003 described the reading interest that the percentage of Indonesian (above 15) reading newspaper on Sunday was only $55.11 \%$, reading magazine was only $29.22 \%$, story book was $16.72 \%$, school textbook $44.28 \%$, and other kind of book was $21.07 \%$. Other data showed that Indonesian did not use book (and other reading) as the information sources.

Švrcková defined reading literacy as an implementation of functional skills gained from certain social context. To be literate, individual should widen their skill and apply it to their daily activity. Hence, literacy was not only restricted on reading ability, but also the ability to work textually, the written communicatiin skill, and information processing based on the text (Švrcková, 2011, p.13).

PISA created literacy scale concluding students' performances in the various aspect of reading literacy with average score 500 for OECD (Organisation for Economid) Co-operation and Development) countries. In addition, two third of the students of those countries had 400 to 600 score. To facilitate the interpretation, literacy scale was devided into five levels. Level 1 represented the students who had serious obstacles to get information through reading. Level 5 represented the students who were able to process the information provided in the unknown texts, to have the detailed understanding about the information provided in a complex text, to deduce the relevant information, to critically evaluate, and to make a hypothesis by using certain ability to

Figure 2 Percentage of students performing at each of the proficiency levels

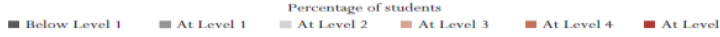

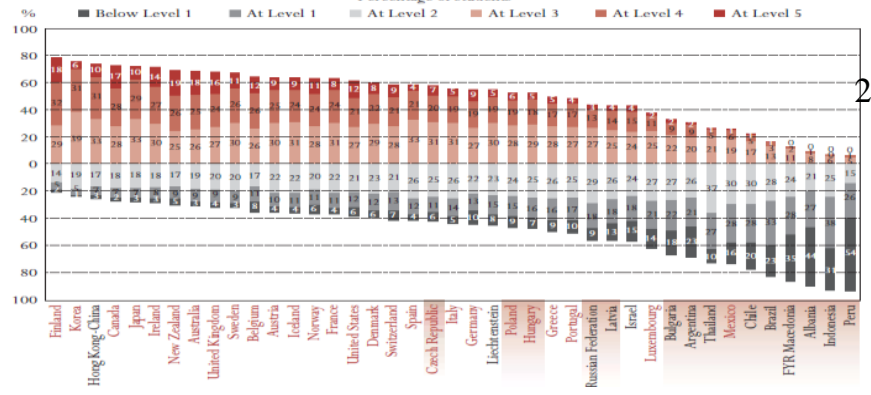

predict the unexpected things. The minimum gap score was 72 point.

The result showed that there were wide differences level of reading literacy among the countries. There was 219 point gap between the highest level country (Finland) and the lowest (Peru) in reading literacy scale. In every country, some 15 year-old children reached the highest level which was level 5. It was shown in figure 2.1. Approximately $10 \%$ of students of OECD countries reached level 5. In contrary, only $0.1 \%$ students of non-OECD countries such as Albania, Indonesia, Macedonia, and Peru could reach level 5, except Hongkong which managed to reach $10 \%$. (Source : OECD PISA, 2000)

\section{Figure 2.1. Students Percentage}

Reading motivation is a strong attention to read accompanied by the sense of pleasure. By reading, people can get some benefit information. Motivation to read must be improved because reading is a necessity. Many factors affects reading motivation. Miller (2015) stated that students tend to be more motivated to read when texts are matched to their instructional levels, when they have opportunities to choose their own books, when they have access to texts that reflect and affirm their cultural identities, and when they can engage in meaningful social interactions with their peers around common texts. In addition, Schutte and Malouff (2007) classified the reading dimensions, such as recognition by others for reading, reading to satisfy curiosity, wishing to avoid difficulties associated with the process of reading (reading work avoidance), the confidence that one can read successfully (reading efficacy), competing with others in reading, social aspects of reading, involvement in text, wanting to comply with others' wishes in regards to reading, reading to achieve high grades, enjoying the challenge of reading difficult material, and believing it is important to be a good reader.

Psychology process inside individual can raise the motivation, which are:

1) Internal factor is motivation factor which is from inside and raises because of one's willing to have achievement and responsibility in their lives. Motivation can thus be seen as an internal factor that causes or guides different types of behaviour and engagement as the observable and unobservable actions associated with reading activities (Unrau \& Quirk in Kirchner \& Mostert, 2017). Internal factors includes: a) pride and achievement, that is motivation to develop the creativity and to reach a goal to increase their self-esteem; b) Needs, every person has their own needs as a motivation to do something to fulfill c) Hope, something to reach in the future which affects the attitude and feeling; d) responsibility; motivation to work well to produce a good result; e) job satisfaction, motivation to do certain job.

2) 2) External factor is motivation from outside. It raises because of the outside influence, for instance organization which affects on someone's behavior. External factors include: a) type and nature of job, is the inner urge to work at certain type and nature of job. This can be affected by

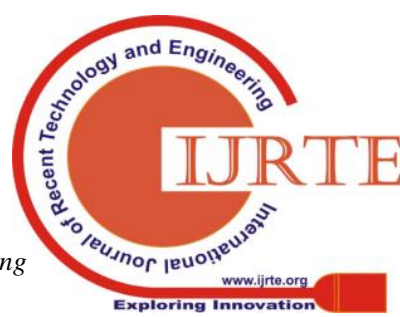


the reward from the job; b) workgroup, is organization where people work to get the salary in order to fulfill their life necessities; c) working condition is a condition where people work condusively as their willing and hope so that they can work well; d) work safety, is the safety given by the organization by giving them assurance; e) interpersonal relationship, is the relationship among colleagues, leader, and the employees. In this case, every person needs to be respected and appreciated to create harmonious working atmosphere.

According to Zainun (2007:19), motivation is caused by basic need. The need will create the urge to make a movement. When a person is encouraged, they will feel imbalance because they will be not satisfied before the needs are fulfilled. The motivation raises as long as the person has needs. Basically, the motivation is the dynamics of needs and encouragement to do an action. Kirchner \& Mosert (2017) quoted that an engagement perspective of reading, as developed by Guthrie and Wigfield (2000), holds that motivation, in combination with strategy use, will result in higher levels of reading achievement.

\section{METHOD}

In this research, the data were collected by using questionnaire. The samples were chosen by applying Stratified Random Sampling to get the data about determinative factors of students' reading interest at community education units in Bandung. The questionnaire was given to the members and adminitrators of the institution/organization (Library, Community Reading Park, Learning centre). Moreover, quantitative and qualitive approach or mix method was applied to this research.

\begin{tabular}{clc}
\hline No. & \multicolumn{1}{c}{ Participant } & $\begin{array}{c}\text { Total } \\
\text { (persons) }\end{array}$ \\
\hline 1. & $\begin{array}{l}\text { Administrator(s) of Bandung } \\
\text { Regional Library and Archieve }\end{array}$ & 4 \\
Office (Dispuip Bandung) & 1 \\
2. & $\begin{array}{l}\text { Administrator(s) of Salman } \\
\text { Reading Corner }\end{array}$ & 3 \\
3. & $\begin{array}{l}\text { Administrator(s) of West Java } \\
\text { Regional Library and Archieve } \\
\text { Office (Dispusipda Jawa Barat) }\end{array}$ & 2 \\
4. & $\begin{array}{l}\text { Administrator(s) of Eco Bambu } \\
\text { reading park (TBM Eco Bambu) }\end{array}$ \\
5. & $\begin{array}{l}\text { Administrator(s) of Elmuloka } \\
\text { reading park (TBM Elmuloka) }\end{array}$ \\
6. Administrator(s) of Bagusrangin \\
7. Administrator(s) of Sukamulya \\
learning centre (PKBM \\
Sukamulya)
\end{tabular}

\section{RESULT AND DISCUSSIONS}

Based on the characteristics of respondents, the following table showed the number of participants involved in this study as well as the respondent percentage:

\begin{tabular}{|c|c|c|c|c|}
\hline NO. & Membership & $\begin{array}{l}\text { Respon } \\
\text { dent } \\
(\%)\end{array}$ & $\begin{array}{c}\text { Perce } \\
\text { ntage } \\
(\%)\end{array}$ & $\begin{array}{c}\text { Total } \\
\text { respondents } \\
\text { (person) }\end{array}$ \\
\hline 1. & Library & 51,6 & $100 \%$ & 129 \\
\hline 2. & $\begin{array}{l}\text { Community } \\
\text { Reading Park }\end{array}$ & 4,4 & $100 \%$ & 11 \\
\hline 3. & CLC & 2 & $100 \%$ & 5 \\
\hline 4. & Non-member & 42 & $100 \%$ & 105 \\
\hline & TOTAL & & & 250 \\
\hline
\end{tabular}

From the data analysis, $51.6 \%$ respondent was taken from library members, $4.4 \%$ from reading park members, $2 \%$ from CLC, and the rest $42 \%$ was from non-member. The respondents taken were the sample to find out the determinative factors of students' reading interest at community education units in Bandung.

Table 4.13

Chacacteristics of Informants

\begin{tabular}{|c|c|c|c|c|c|}
\hline \multirow[b]{2}{*}{ No. } & \multirow[b]{2}{*}{$\begin{array}{c}\text { Indicat } \\
\text { ors }\end{array}$} & \multicolumn{4}{|c|}{ Respondent's Result } \\
\hline & & Highest & $\begin{array}{c}\text { Frequ } \\
\text { ency } \\
(f)\end{array}$ & Lowest & $\begin{array}{c}\text { Frequ } \\
\text { ency } \\
(f)\end{array}$ \\
\hline 1. & Sex & $\begin{array}{l}\text { Female } \\
(73,2 \%)\end{array}$ & 183 & $\begin{array}{l}\text { Male } \\
(26,8 \%)\end{array}$ & 67 \\
\hline 2. & Age & $\begin{array}{l}19-23 \\
\text { years old } \\
(48 \%)\end{array}$ & 120 & $\begin{array}{l}<15 \\
\text { years old } \\
(0,4 \%) \\
>55 \\
\text { tahun } \\
(0,4 \%)\end{array}$ & 1 \\
\hline 3. & $\begin{array}{c}\text { Level of } \\
\text { Educati } \\
\text { on }\end{array}$ & $\begin{array}{l}\text { Senior } \\
\text { High } \\
\text { school } \\
(44,4 \%)\end{array}$ & 111 & $\begin{array}{l}\text { Primary } \\
\text { School } \\
(0,4 \%)\end{array}$ & 1 \\
\hline 4. & $\begin{array}{c}\text { Types of } \\
\text { Job }\end{array}$ & $\begin{array}{l}\text { Students } \\
(65,2 \%)\end{array}$ & 163 & $\begin{array}{l}\text { Govern } \\
\text { ment } \\
\text { Employe } \\
\text { es } \\
(3,2 \%)\end{array}$ & 8 \\
\hline
\end{tabular}

Based on table 4.13, there were more female respondents (73.2\%). The age was approximately from 19 to 23 years old and they were students of senior high school and university. In contrary, the male respondents were only $26.8 \%$ which were under 15 to above 50 years old. The lowest level of education was primary school. Some respondents were government employees.

\section{A. Aspect of Reading Interest}


Table 4.15

Aspects of Reading Interest

\begin{tabular}{|c|c|c|c|c|c|c|}
\hline \multirow[b]{2}{*}{ No. } & \multirow[b]{2}{*}{ Indicators } & \multicolumn{4}{|c|}{ Result } & \multirow[b]{2}{*}{ Total } \\
\hline & & $\begin{array}{l}\text { YE } \\
\mathbf{S}\end{array}$ & $\begin{array}{l}\text { Frequ } \\
\text { ency } \\
(f)\end{array}$ & NO & $\begin{array}{l}\text { Frequ } \\
\text { ency } \\
(f)\end{array}$ & \\
\hline 1. & $\begin{array}{l}\text { Taking their } \\
\text { time to visirt } \\
\text { Library/read } \\
\text { ing } \\
\text { park/CLC }\end{array}$ & $\begin{array}{c}67,6 \\
\%\end{array}$ & 169 & $\begin{array}{c}32,4 \\
\%\end{array}$ & 81 & 250 \\
\hline 2. & $\begin{array}{l}\text { Visiting } \\
\text { library/readi } \\
\text { ng } \\
\text { park/CLC } \\
\text { and } \\
\text { borrowing } \\
\text { books }\end{array}$ & $\begin{array}{c}86,4 \\
\%\end{array}$ & 216 & $\begin{array}{c}13,6 \\
\%\end{array}$ & 34 & 250 \\
\hline 3. & $\begin{array}{l}\text { Visiting } \\
\text { library/readi } \\
\text { ng } \\
\text { park/CLC } \\
\text { because of } \\
\text { the benefits }\end{array}$ & $\begin{array}{c}93,6 \\
\%\end{array}$ & 234 & $\begin{array}{c}6,4 \\
\%\end{array}$ & 16 & 250 \\
\hline 4. & $\begin{array}{l}\text { Visiting } \\
\text { library/readi } \\
\text { ng } \\
\text { park/CLC to } \\
\text { study }\end{array}$ & $\begin{array}{l}90 \\
\%\end{array}$ & 225 & $10 \%$ & 25 & 250 \\
\hline 5. & $\begin{array}{l}\text { Visiting } \\
\text { library/readi } \\
\text { ng } \\
\text { park/CLC } \\
\text { because of } \\
\text { their future } \\
\text { goals. }\end{array}$ & $\begin{array}{c}81,2 \\
\%\end{array}$ & 203 & $\begin{array}{c}18,8 \\
\%\end{array}$ & 47 & 250 \\
\hline
\end{tabular}

From five indicators in table 4.15, most of the respondent answered 'YES'. 67.6\% respondents took their time to visit library/reading park/CLC; $86.4 \%$ respondents visited library/reading park/CLC to borrow book, $93.6 \%$ respondent visited library/reading park/CLC because its benefits; $90 \%$ respondents visited library/reading park/CLC to study and 81.2 respondents visited library/reading park/CL because of their future goals. The respondents answering 'NO' to those indicators were $32.4 \%$ for taking the time to visit library/reading park/CLC; $13.6 \%$ did not visit library/reading park/CLC to borrow books; $6.4 \%$ did not visit library/reading park/CLC because of the benefits; $10 \%$ respondent did not visit library/reading park/CLC to study; and $18.8 \%$ respondents did not visit library/reading park/CLC because of their future goals.

\section{B. Aspects of Reading Motivation}

Table 4.16

Reading Motivation

\begin{tabular}{|c|c|c|c|c|c|c|}
\hline \multirow[b]{2}{*}{ No } & \multirow[b]{2}{*}{ Indicator } & \multicolumn{4}{|c|}{ Result } & \multirow[b]{2}{*}{ Total } \\
\hline & & $\begin{array}{c}\mathbf{Y E} \\
\mathbf{S}\end{array}$ & $\begin{array}{c}\text { Frequ } \\
\text { ency } \\
(f)\end{array}$ & NO & $\begin{array}{c}\text { Fre } \\
\text { que } \\
\text { ncy } \\
(f)\end{array}$ & \\
\hline 1. & $\begin{array}{l}\text { Reading } \\
\text { pleasure }\end{array}$ & 93,2 & 233 & $\begin{array}{c}6,8 \\
\%\end{array}$ & 17 & 250 \\
\hline
\end{tabular}

\begin{tabular}{|c|c|c|c|c|c|c|}
\hline \multirow[b]{2}{*}{ No } & \multirow[b]{2}{*}{ Indicator } & \multicolumn{4}{|c|}{ Result } & \multirow[b]{2}{*}{ Total } \\
\hline & & $\begin{array}{c}\text { YE } \\
\mathbf{S}\end{array}$ & $\begin{array}{c}\text { Frequ } \\
\text { ency } \\
(f)\end{array}$ & NO & $\begin{array}{c}\text { Fre } \\
\text { que } \\
\text { ncy } \\
(f)\end{array}$ & \\
\hline & & $\%$ & & & & \\
\hline 2. & $\begin{array}{l}\text { Reading } \\
\text { encouragem } \\
\text { ent }\end{array}$ & $\begin{array}{c}88,8 \\
\%\end{array}$ & 222 & $\begin{array}{c}11,2 \\
\%\end{array}$ & 28 & 250 \\
\hline 3. & $\begin{array}{l}\text { Friend with } \\
\text { same } \\
\text { interest }\end{array}$ & $\begin{array}{l}72 \\
\%\end{array}$ & 180 & $28 \%$ & 70 & 250 \\
\hline 4. & $\begin{array}{l}\text { Inviting } \\
\text { friend to } \\
\text { join in }\end{array}$ & $\begin{array}{l}68 \\
\%\end{array}$ & 170 & $\begin{array}{l}32 \\
\%\end{array}$ & 80 & 250 \\
\hline 5. & $\begin{array}{l}\text { Friend as } \\
\text { motivation }\end{array}$ & $\begin{array}{c}67,2 \\
\%\end{array}$ & 168 & $\begin{array}{c}32,8 \\
\%\end{array}$ & 82 & 250 \\
\hline
\end{tabular}

Table 4.16 showed the reading motivation divided into five indicators. Based on it, there were $93.23 \%$ of the respondents who read because of the sense of pleasure; $88.8 \%$ of the respondents read because of the encouragement; $72 \%$ of respondents has the same interest as their friend in reading; $68 \%$ of the respondents invited their friend to join in library/reading park/CLC, and $67.2 \%$ of the respondents has the reading motivation from their friends. The respondents answering 'NO' to those indicators were $6.8 \%$ who did not feel the reading pleasure; $11.2 \%$ did not have reading encouragement; $28 \%$ did not have friends with same interest; $32 \%$ of the respondents did not inviting their froend to join; and $32.8 \%$ of the respondents did not have the reading motivation from their friends.

\section{Learning Group Aspects}

Table 4.17 Learning Group

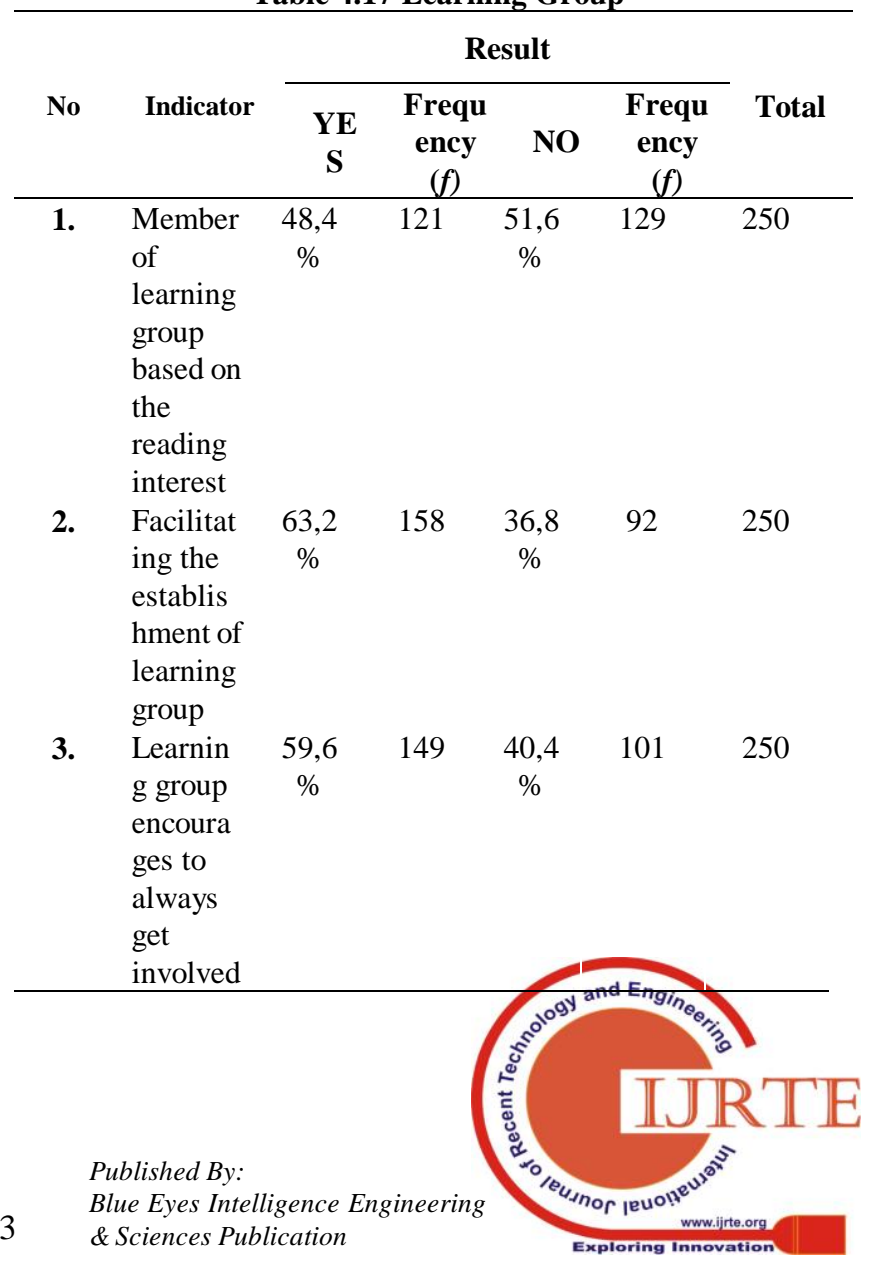


There were three aspects presented in table 4.17. The first aspect was that the respondent is a member of a learning group. The result showed that $51.6 \%$ of the respondents was not a member of learning group and $48.4 \%$ of the respondents was a member. The second aspect was that library/reading park/CLC facilitated the establishment of a learning group. The result showed that more than half of the total respondents answered 'YES' with $63.2 \%$ and $36.8 \%$ others answered 'NO'. The third aspect was that the learning group encourage them to always get involved. The result showed that $59.6 \%$ of the respondents agreed with it and $40.4 \%$ of the respondent disagreed.

\section{Learning Sources Aspect}

Table 4.18

Learning Sources

\begin{tabular}{|c|c|c|c|c|c|c|}
\hline \multirow[b]{2}{*}{ No } & \multirow[b]{2}{*}{ Indicators } & \multicolumn{4}{|c|}{ Result } & \multirow[b]{2}{*}{ Total } \\
\hline & & Yes & $\begin{array}{l}\text { Freq } \\
\text { uenc } \\
y(f)\end{array}$ & No & $\begin{array}{l}\text { Freq } \\
\text { uenc } \\
\text { y }(f)\end{array}$ & \\
\hline 1. & $\begin{array}{l}\text { Various } \\
\text { learning } \\
\text { sources }\end{array}$ & $\begin{array}{c}94,4 \\
\%\end{array}$ & 236 & $\begin{array}{c}5,6 \\
\%\end{array}$ & 14 & 250 \\
\hline 2. & $\begin{array}{l}\text { Learning } \\
\text { sources by } \\
\text { the } \\
\text { organization } \\
\text { based on the } \\
\text { interest }\end{array}$ & $\begin{array}{c}89,6 \\
\%\end{array}$ & 224 & $\begin{array}{c}10,4 \\
\%\end{array}$ & 26 & 250 \\
\hline 3. & $\begin{array}{l}\text { Guidance } \\
\text { from the } \\
\text { administrato } \\
\text { rs }\end{array}$ & $\begin{array}{c}62,8 \\
\%\end{array}$ & 157 & $\begin{array}{c}37,2 \\
\%\end{array}$ & 93 & 250 \\
\hline 4. & $\begin{array}{l}\text { Training } \\
\text { based on the } \\
\text { need }\end{array}$ & $\begin{array}{c}66,8 \\
\%\end{array}$ & 167 & $\begin{array}{c}33,2 \\
\%\end{array}$ & 83 & 250 \\
\hline 5. & $\begin{array}{l}\text { Administrat } \\
\text { ors help } \\
\text { when there } \\
\text { are } \\
\text { problems } \\
\text { faced by } \\
\text { members }\end{array}$ & $\begin{array}{c}87,6 \\
\%\end{array}$ & 219 & $\begin{array}{c}12,4 \\
\%\end{array}$ & 31 & 250 \\
\hline
\end{tabular}

Based on the table 4.18, in the first indicator, most of the respondent said that there were various learning resources to support the learning process. The percentage was $94.4 \%$ of Yes and $5.6 \%$ of No. In the second indicators, $89.6 \%$ respondents agree that the organization facilitated them with learning recources as their interest; and the other $10.4 \%$ disagree. $62 \%$ of the respondents said that they were accompanied by the administrator and got the guidance during the learning process; $37.2 \%$ answered that they did not get the guidance from the administrators. $66.8 \%$ of the respondents said that they were facilitated with a training based on their need; $33.2 \%$ of respondents disagree with the statement. $87.6 \%$ of the respondents said that the administrators helped them when facing a problem during the learning process and $12.4 \%$ said the otherwise.

\section{E. Program Continuity Aspect}

Tabel 4.22 Program Continuity

\begin{tabular}{|c|c|c|c|c|c|c|}
\hline \multirow[b]{2}{*}{ No. } & \multirow[b]{2}{*}{ Indicators } & \multicolumn{4}{|c|}{ Result } & \multirow[b]{2}{*}{ Total } \\
\hline & & YES & $\begin{array}{c}\text { Frequ } \\
\text { ency } \\
(f)\end{array}$ & $\mathrm{NO}$ & $\begin{array}{l}\text { Frequ } \\
\text { ency } \\
(f) \\
\end{array}$ & \\
\hline 1. & $\begin{array}{l}\text { Members } \\
\text { can } \\
\text { participate } \\
\text { financially } \\
\text { for the } \\
\text { continuity } \\
\text { of the } \\
\text { program }\end{array}$ & $\begin{array}{c}79,6 \\
\%\end{array}$ & 199 & $\begin{array}{c}20,4 \\
\%\end{array}$ & 51 & 250 \\
\hline 2. & $\begin{array}{l}\text { Members } \\
\text { are ready } \\
\text { to } \\
\text { participate } \\
\text { financially }\end{array}$ & $\begin{array}{c}75,6 \\
\%\end{array}$ & 189 & $\begin{array}{c}24,4 \\
\%\end{array}$ & 61 & 250 \\
\hline 3. & $\begin{array}{l}\text { Interesting } \\
\text { programs }\end{array}$ & $\begin{array}{c}77,6 \\
\%\end{array}$ & 194 & $\begin{array}{c}22,4 \\
\%\end{array}$ & 56 & 250 \\
\hline 4. & $\begin{array}{l}\text { Reward for } \\
\text { the active } \\
\text { members }\end{array}$ & $\begin{array}{c}53,2 \\
\%\end{array}$ & 133 & $\begin{array}{c}46,8 \\
\%\end{array}$ & 117 & 250 \\
\hline
\end{tabular}

Based on table 4.22 showed the indicators about program continuity. $79.6 \%$ of the respondents said that the members could participate financially to support the continuity of the program in Library/CLC/reading park. Supporting the statement, $75.6 \%$ of the respondents also said that they were ready to participate financially for the continuity of the Library/CLC/reading park program. In contrary, $20.4 \%$ of the respondent said that the members could not participate for the continuity of the program in the library/CLC/reading park and $24.4 \%$ of the respondents were not ready to participate financially. About the program in the library/CLC/reading park, $77.6 \%$ of the respondents answered that the program was interesting while $22.4 \%$ of the respondents did not agree with the statement. More than half of the respondent which was $53.2 \%$ stated that the library/CLC/reading park rewarded the active members. With a close gap, respondents who stated that the library/CLC/reading park did not reward the active members reached $46.8 \%$.

\section{F.Developing Interest in Reading Aspect}

Table 4.23 Developing the Interest in Reading

\begin{tabular}{|c|c|c|c|c|c|c|}
\hline \multirow[b]{2}{*}{ No } & \multirow[b]{2}{*}{ Indicators } & \multicolumn{4}{|c|}{ Result } & \multirow[b]{2}{*}{ Total } \\
\hline & & $\begin{array}{c}\mathbf{Y E} \\
\mathbf{S}\end{array}$ & $\begin{array}{l}\text { Fre } \\
\text { que } \\
\text { ncy } \\
(f) \\
\end{array}$ & NO & $\begin{array}{l}\text { Fre } \\
\text { que } \\
\text { ncy } \\
(f) \\
\end{array}$ & \\
\hline 1. & $\begin{array}{l}\text { Conducting } \\
\text { various } \\
\text { programs }\end{array}$ & $\begin{array}{c}64,4 \\
\%\end{array}$ & 161 & $\begin{array}{c}35,6 \\
\%\end{array}$ & 89 & 250 \\
\hline 2. & $\begin{array}{l}\text { Active in } \\
\text { another } \\
\text { conducted } \\
\text { activities }\end{array}$ & $\begin{array}{c}52,4 \\
\%\end{array}$ & 131 & $\begin{array}{c}47,6 \\
\%\end{array}$ & 119 & 250 \\
\hline 3. & $\begin{array}{l}\text { Programs } \\
\text { based on the } \\
\text { interest and } \\
\text { need }\end{array}$ & $\begin{array}{c}72,8 \\
\%\end{array}$ & 182 & 27,2 & 68 & 250 \\
\hline
\end{tabular}




\begin{tabular}{|c|c|c|c|c|c|c|}
\hline \multirow[b]{2}{*}{ No } & \multirow[b]{2}{*}{ Indicators } & \multicolumn{4}{|c|}{ Result } & \multirow[b]{2}{*}{ Total } \\
\hline & & $\begin{array}{c}\text { YE } \\
\mathbf{S}\end{array}$ & $\begin{array}{l}\text { Fre } \\
\text { que } \\
\text { ncy } \\
(f)\end{array}$ & NO & $\begin{array}{c}\text { Fre } \\
\text { que } \\
\text { ncy } \\
(f)\end{array}$ & \\
\hline 4. & $\begin{array}{l}\text { Get the } \\
\text { knowledge } \\
\text { by being a } \\
\text { member }\end{array}$ & $\begin{array}{c}89,2 \\
\%\end{array}$ & 223 & $\begin{array}{c}10,8 \\
\%\end{array}$ & 27 & 250 \\
\hline 5. & $\begin{array}{l}\text { Reading can } \\
\text { help in } \\
\text { doing my } \\
\text { job/work }\end{array}$ & $\begin{array}{c}93,2 \\
\%\end{array}$ & 233 & $\begin{array}{c}6,8 \\
\%\end{array}$ & 17 & 250 \\
\hline 6. & $\begin{array}{l}\text { Reading can } \\
\text { help to reach } \\
\text { the life goals }\end{array}$ & $\begin{array}{c}92,8 \\
\%\end{array}$ & 232 & $\begin{array}{c}7,2 \\
\%\end{array}$ & 18 & 250 \\
\hline
\end{tabular}

There were six indicators presented in table 4.23. The first indiator was that the library/CLC/Reading Park condacted various program. 64\% responded 'YES'to this statement and $35.6 \%$ responded 'NO. Based on the second indicator which was about another activity conducted by the library/CLC/Reading Park, 52.4\% of the respondents said that they did not join in another activity and $47.6 \%$ of the respondents said that they joined in that activity. The third indicator was that the program condacted by the Library/CLC/Reading Park were suitable wit the members' need and interest. $72.8 \%$ of the respondents agreed with the statement while $27.2 \%$ others disagreed. $89.2 \%$ of the respondents said YES as their respond to the forth indicator that they got new knowledge by being a member of library/CLC/reading park and $10.8 \%$ said the otherwise. Most of the respondents (93.2\%) said that reading can help them in doing their job/work as presented in the fifth indicators. Only $6.8 \%$ of the respondents said that reading could not help them in their work. Another big percentage of the agreement was also showed in the sixth indicator which stated that reading can help the members to reach their life goals. The percentage reached $92.8 \%$ and only $7.2 \%$ showed their disagreement.

\section{G. Reading Pleasure as the Mission of the Organization Aspect}

Table 4.24 Reading Pleasure as the Mission

\begin{tabular}{|c|c|c|c|c|c|c|}
\hline \multirow[b]{2}{*}{ No. } & \multirow[b]{2}{*}{ Indicators } & \multicolumn{4}{|c|}{ Result } & \multirow[b]{2}{*}{ Total } \\
\hline & & $\begin{array}{c}\mathbf{Y E} \\
\mathbf{S}\end{array}$ & $\begin{array}{c}\text { Fre } \\
\text { que } \\
\text { ncy } \\
(f)\end{array}$ & NO & $\begin{array}{c}\text { Frequ } \\
\text { ency } \\
(f)\end{array}$ & \\
\hline 1. & $\begin{array}{l}\text { Membership } \\
\text { encourage to } \\
\text { be active in } \\
\text { the } \\
\text { community }\end{array}$ & $\begin{array}{l}78 \\
\%\end{array}$ & 195 & $\begin{array}{l}22 \\
\%\end{array}$ & 55 & 250 \\
\hline 2. & $\begin{array}{l}\text { Wise in } \\
\text { taking the } \\
\text { decision } \\
\text { when } \\
\text { becoming a } \\
\text { member }\end{array}$ & $\begin{array}{c}76,4 \\
\%\end{array}$ & 191 & $\begin{array}{c}23,6 \\
\%\end{array}$ & 59 & 250 \\
\hline 3. & $\begin{array}{l}\text { Feel the } \\
\text { satisfaction } \\
\text { of the }\end{array}$ & $\begin{array}{c}79,6 \\
\%\end{array}$ & 199 & $\begin{array}{c}20,4 \\
\%\end{array}$ & 51 & 250 \\
\hline
\end{tabular}

\begin{tabular}{llccccc}
\hline & & \multicolumn{5}{c}{ Result } \\
\cline { 3 - 5 } No. & Indicators & YE & $\begin{array}{c}\text { Fre } \\
\text { que } \\
\text { ncy } \\
(f)\end{array}$ & No & $\begin{array}{c}\text { Frequ } \\
\text { ency } \\
(f)\end{array}$ & \\
\hline 4. & $\begin{array}{l}\text { achivment } \\
\text { Develop the } \\
\text { interest in } \\
\text { reading }\end{array}$ & $\begin{array}{c}87,2 \\
\%\end{array}$ & 218 & 12,8 & 32 & 250 \\
& & & & & \\
\hline
\end{tabular}

Table 4.24 presented four indicators of the reading pleasure as the mission of the library/CLC/reading park. The first indicator stated that the membership of library/CLC/readingpark gave the members encouragement to be active in the community. As the responds, $78 \%$ of the respondents answerednwith 'YES' and 22\% of the respondents answered with 'NO'. The second indicator was that the members of library/CLC/reading park took decision wisely after being a member. $76.4 \%$ of the respondents agreed with the statement while the others $(23.6 \%)$ disagreed. $76.9 \%$ of the respondents said that they feel the satisfaction of their learning achievent in library/CLC/reading park as indicated in the third indicators. In contrary, $20.4 \%$ of the respondents did not feel good with their learning achievement. The forth indicator was that library/CLC/reading park can develop the members' interest in reading. Most of the respondents (87.2\%) answered it with YES while $12.8 \%$ said that library/CLC/reading park did not develop their reading interest. According to A.M. Sardiman (2005:75), psychology process which raises motivation from the inside was affected by two factors: internal factor and external factor. This was relevant to the finding as the following charts.

Table 4.25Internal Factors

\begin{tabular}{|c|c|c|c|c|}
\hline \multicolumn{5}{|c|}{ Internal Factors } \\
\hline $\begin{array}{l}\text { pride and } \\
\text { achievement } \\
\text { : resercher's } \\
\text { finding } \\
\text { showed that } \\
46.8 \% \text { of } \\
\text { ther } \\
\text { respondents } \\
\text { felt that the } \\
\text { institution/o } \\
\text { rganization } \\
\text { rewarded } \\
\text { them as the } \\
\text { appreciation } \\
\text { to the active } \\
\text { members. }\end{array}$ & $\begin{array}{l}\text { needs : the } \\
\text { findings } \\
\text { showed } \\
\text { that } 72.8 \% \\
\text { of the } \\
\text { respondent } \\
\text { s stated } \\
\text { that the } \\
\text { program } \\
\text { conducted } \\
\text { by the } \\
\text { institusion/ } \\
\text { organizatio } \\
\text { n met their } \\
\text { needs and } \\
\text { interest. }\end{array}$ & $\begin{array}{l}\text { hope : } \\
\text { the } \\
\text { finding } \\
\text { showed } \\
\text { that } \\
81.2 \% \text { of } \\
\text { the } \\
\text { responde } \\
\text { nts } \\
\text { visited } \\
\text { the } \\
\text { library } \\
\text { because } \\
\text { it could } \\
\text { help } \\
\text { them } \\
\text { with } \\
\text { their } \\
\text { future } \\
\text { goals. }\end{array}$ & $\begin{array}{l}\text { responsilb } \\
\text { ility: inthe } \\
\text { findings, } \\
93.2 \% \text { of } \\
\text { the } \\
\text { respondent } \\
\text { s stated } \\
\text { that } \\
\text { reading in } \\
\text { the } \\
\text { library/clc/ } \\
\text { reading } \\
\text { park can } \\
\text { help them } \\
\text { in } \\
\text { finishing } \\
\text { their } \\
\text { work/duty }\end{array}$ & $\begin{array}{l}\text { job } \\
\text { satisfactio } \\
\mathrm{n} \text { : } \\
\text { job } \\
\text { satisfactio } \\
\mathrm{n} \text { raised } \\
\text { after we } \\
\text { can feel } \\
\text { the } \\
\text { change. } \\
\text { the } \\
\text { researcher } \\
\text { found out } \\
\text { that } 89.2 \% \\
\text { of the } \\
\text { responden } \\
\text { ts feel the } \\
\text { change } \\
\text { after being } \\
\text { a member } \\
\text { in } \\
\text { library/clc } \\
\text { /reading } \\
\text { park }\end{array}$ \\
\hline
\end{tabular}


Table 4.26

External Factors

\begin{tabular}{|c|c|c|c|}
\hline \multicolumn{4}{|c|}{ EXTERNAL FACTORS } \\
\hline $\begin{array}{l}\text { Types And } \\
\text { Nature Of } \\
\text { Job: The } \\
\text { Findings } \\
\text { Showed } \\
\text { That } \\
65.2 \% \text { Of } \\
\text { The } \\
\text { Responde } \\
\text { nts Were } \\
\text { High } \\
\text { School Or } \\
\text { University } \\
\text { Students }\end{array}$ & $\begin{array}{l}\text { Learning } \\
\text { Group: } \\
\text { Because } \\
\text { This Study } \\
\text { Was About } \\
\text { Education, } \\
\text { The } \\
\text { Researchers } \\
\text { Found Out } \\
\text { That 48.4\% } \\
\text { Of The } \\
\text { Respondent } \\
\text { s Was A } \\
\text { Member Of } \\
\text { A Learning } \\
\text { Group As } \\
\text { Their } \\
\text { Interest. }\end{array}$ & $\begin{array}{l}\text { Environment } \\
\text { Condition: } \\
\text { The } \\
\text { Researcher } \\
\text { Found Out } \\
\text { That 93.2\% } \\
\text { Of The } \\
\text { Respondents } \\
\text { Felt That The } \\
\text { Reading } \\
\text { Room In The } \\
\text { Library/Clc/R } \\
\text { eading Park } \\
\text { Was } \\
\text { Comfortable } \\
\text { To } \\
\text { Reading Do } \\
\text { Activity } \\
\text { Condusively }\end{array}$ & $\begin{array}{l}\text { INTERPERSO } \\
\text { NAL } \\
\text { RELATIONSHI } \\
\text { P: the researche } \\
\text { found out that } \\
59.6 \% \text { of the } \\
\text { respondents delt } \\
\text { that the learning } \\
\text { group } \\
\text { encouraged } \\
\text { them to always } \\
\text { involve in } \\
\text { learning } \\
\text { activities. }\end{array}$ \\
\hline
\end{tabular}

From the previous chart. The researcher concluded that there were internal and external factors as the determinative factors of students' reading interest at community education units. Internal factors is motivation factor which is from inside and raises because of one's willing to have achievement and responsibility in their lives. Researcher found out that there were five internal factors. The first was the pride; reward given from the library/CLC/reading park was need to appreciate themselves so it would raise new motivation to read. The second factor was needs; the library/CLC/reading park met the learning need of the members. The third factor was hope; it seemed that members visited library/CLC/reading park because it could help them to reach their future goals. In the term of responsibility, reading could help the members to finish their work or duty. The latter factor raised their job satisfaction.

The internal factors was the way of a person in fulfilling their willing from the inside. Supporting the willing, there were also external factors which were types and nature of job, learning group, environment condition, and interpersonal relationship. People with similar type and nature of job would build the same goals and it encouraged them to form a learning group as a helpful way to solving problems. The comfortable and condusive environment and proper facilities also supported the learning activities and built good relationship among the members and administrators. These factors affected the number of visit and the motivation level of the members to be active in learning activities as well as their interest in reading.

\section{CONCLUSION}

This study was about the determinative factors of students' reading interest at community education units in Bandung. The researcher did an interview, observation, and questionnaire. Based on the respindents, researcher concluded that there were some determinative factors of students' reading interest divided into internal factors and external factors. Internal factor is motivation factor which is from inside and raises because of one's willing to have achievement and responsibility in their lives. To support the willing, there were also external factors which were types and nature of job, learning group, environmental condition, and interpersonal relationship. It was said that the same type of job will encourage the people to form a learning group as a helpful way to reach the goals together.

\section{Acknowledgement}

We would like to express our deepest gratitude to Department of Community Education for the research opportunity. We would like to also appreciate TBM and Perpustakaan as the partner who has helped the research from the beginning till its completion.

\section{REFERENCES}

1. Abdulhak, I.. Metodologi Pembelajaran Orang Dewasa, Bandung: Andira. 2000

2. Abin Syamsudin Makmun, Psikologi Kependidikan, Jakarta: Remaja Rosda Karya. 2001

3. Ahmadi, Abu. Psikologi Sosial. Jakarta: PT. Rineka Cipta. 2009

4. Baderi, H. A. Meningkatkan Minat Baca Masyarakat melalui Suatu Kelembagaan Nasional, Wacana ke Arah Pembentukan Sebuah Lembaga Nasional Pembudayaan Masyarakat Membaca. Orasi Ilmiah Pengukuhan Pustakawan Utama. Jakarta: Perpustakaan Nasional Republik Indonesia. 2005.

5. Budi, Taufiq. Pedoman Pembudayaan Kegemaran Membaca. Bandung: Dinas Perpustakaan dan Kearsipan Daerah Provinsi Jawa Barat. . 2018

6. Djuju, Sudjana S.. Pendidikan Luar Sekolah: Wawasan, Sejarah Perkembangan, Falsafa \& Teori Pendukung. Bandung: Falah Production. 2001

7. Faisal, S. Paradigma Baru Pendidikan Keaksaraan, Tawaran Bagi Pengembangan Program Keaksaraan di Indonesia. Jakarta: Dirjen PLS, Depdiknas. 2006

8. Harian Umum Kompas. Pengembangan Minat Baca, Tanggungjawab Orang tua. Jakarta: Harian Umum Kompas tanggal 4 Nopember 1996.

9. Hatimah, I., Pembelajaran Berwawasan Kemasyarakatan, Jakarta: Universitas Terbuka. 2008.

10. Kalida, Muhsin dkk. TBM di PKBM: Model dan Strategi Pengembangannya. Yogyakarta: Cakruk Publishing. 2014

11. Kamil, M. Pusat Budaya dan Belajar Masyarakat, PKBM (Indonesia) dan Kominkan (Jepang). Bandung: Penerbit Dewa Ruchi. 2008

12. Karmidah dkk. Model Taman Bacaan Masyarakat: Pusat Penelitian Kebijakan dan Inovasi Pendidikan Badan Penelitian dan Pengembangan Kemendiknas Jakarta. 2009.

13. Kartono, K. Pengantar Metode Riset Sosial, Bandung: Mandar Maju. 1996.

14. Kirchner, E., \& Moster, M.L. Aspects of the reading motivation and reading activity of Namibian primary school readers. Cogent Education. 2017.

15. Kusnadi. Pendidikan Keaksaraan, Filosofi, Strategi, dan Implementasi Jakarta: Dirjen PLS, Depdiknas. 2005.

16. Lasa. Manajemen Perpustakaan Sekolah. Yogyakarta: Pinus. 2007.

17. Meichati, S. Motivasi Pembaca. Yogyakarta : Universitas Gadjah Mada. 1978

18. Moleong. Metode Penelitian Kualitatif. Bandung: Remaja Rosdakarya 2002.

19. Nurrohmah, Oom. Pedoman Pembudayaan Kegemaran Membaca. Bandung: Dinas Perpustakaan dan Kearsipan Daerah. 2018.

20. Pemerintah Propinsi Jawa Barat. Rencana Strategik Bapusda. Propinsi Jawa Barat tahun 2003-2008. Bandung: Bapusda Propinsi Jawa Barat 2003.

21. Perpustakaan Nasional RI. Panduan Koleksi Perpustakaan Khusus. Jakarta: Perpustakaan Nasional RI. 1992.

22. Sedyowati, Edi. Promosi Gemar Membaca. Jakarta: Menneg Koordinator. Bidang Politik dan Keamanan RI. 1994.

23. Shahab, Ali. Apresiasi Masyarakat Terhadap Perpustakaan. Jakarta: Centra Focus. 2003. 
24. Sondang P. Siagian. Teori Motivasi dan Aplikasinya. Jakarta: PT. Rineka Cipta. 2004.

25. Sugiono. Metode Penelitian Kualitatif dan Kuantitatif. Bandung: CV. Alfabeta. 2011.

26. Suherman. Perpustakaan sebagai Jantung Sekolah: referensi pengelolaan sekolah. Bandung: MQS Publishing. 2009.

27. Sutarno NS. Perpustakaan dan Masyarakat. Jakarta: Sagung Seto. 2006

28. Suyono, A.,H. Memupuk Minat Baca Anak. Intisari Mei 1998, halaman 106-113.

29. Tarigan, Henry Guntur. Membaca sebagai Suatu Keterampilan Berbahasa. Bandung: Angkasa. 1979. Jounal Source:

30. Demokrawati. F. A. Analisis Quick Count dengan Menggunakan Metode Stratified Random Sampling (Studi Kasus Pemilu Walikota Bandung 2013). Universitas Pendidikan Indonesia, 1. 2014.

31. Hamjah, Salasiah H, dkk. Methods of Increasing Learning Motivation among Students. 2010. 138-147

32. Hubackova, S., \& Semradova, I. Research Study on Motivation in Adult Education. Procedia - Social and Behavioral Science. 2014. 159, 396-400. doi:10.1016/j.sbspro.2014.12.395

33. Leorke, D., Wyatt, D., \& McQuire, S. "More than just a library”: Public libraries in the "smart city." City, Culture and Society. 2018. doi:10.1016/j.ccs.2018.05.002

34. Martínez-Guido, S. I., González-Campos, J. B., \& Ponce-Ortega, J. M Strategic Planning to Improve the Human Development Index in Disenfranchised Communities through Satisfying Food, Water and Energy Needs. Food and Bioproducts Processing. 2019. doi:10.1016/j.fbp.2019.06.007

35. Miller, R. Learning to love reading: A self-study on fostering students reading motivation in small groups, Studying Teacher Education. 2015 11:2, 103-123, DOI: 10.1080/17425964.2015.1045771

36. Pezoa, J. P., Mendive, S., \& Strasser, K. Reading interest and family literacy practices from prekindergarten to kindergarten: Contributions from a cross-lagged analysis. Early Childhood Research Quarterly. 2019. 47, 284-295. doi:10.1016/j.ecresq.2018.12.014

37. Schutte, N.S. \& Malouff, J.F. Dimensions of reading motivation: Development of an adult reading motivation scale, Reading Psychology. 2007. 28:5, 469-489, DOI: 10.1080/02702710701568991

38. Organisation For Economic Co-operation And Development Unesco Insititute For Statitics (OECD). Literacy Skills For The World Of Tomorrow: Further Results. 2000. 1-23

39. Sardjunani, Nina. Increasing Literacy In Indonesia . 2005. 1-21

40. Kusuma, Chusnu Syarifa D. Counteract Hoax Through Reading Interest Motivation. 2017. 34-54

41. Karyono, Hari. Menumbuhkan Minat Baca Sejak Usia Dini. 2012. 1-12

42. Saepudin, Encang. Tingkat Budaya Membaca Masyarakat: Studi Kasus Pada Masyarakat Di Kabupaten Bandung. Vol.3/No.2. 2015. 271-282

43. Sofyan, Hamzah. Meningkatkan Motivasi Membaca. Vol 09/No.2. 2015. $17-27$

44. Hiemstra, Roger. The Community School (the informal education archives). Diakses [online] http://infed.org/archives/e-texts/hiemstra_community_school.htm. 2019.

45. Peraturan Daerah Pemerintah Propinsi Jawa Barat nomor 1 tahun 2003 .Tentang Rencana Strategik Pemerintah Propinsi Jawa Barat tahun 2003 2008.

46. Peraturan Daerah Kota Bandung No. 13 Tahun 2015 tentang Penyelenggaraan Perpustakaan

47. Undang-undang Republik Indonesia No. 43 Tahun 2007 Tentang Perpustakaan

\section{AUTHORS PROFILE}

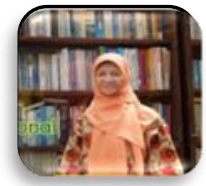

Rita Kustari Koesma, doctoral student at community education Department, Universitas Pendidikan Indonesia. a social librarian in bandung city. The owner of Rita Home Library. Education Fighter for Everyone.

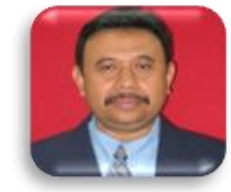

Achmad Hufad, Professor at community education Department, Universitas Pendidikan Indonesia. Researcher in Social Sciences and Cultures.

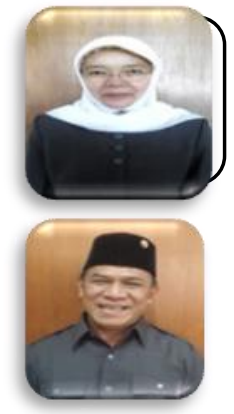

Ihat Hatimah, Professor at Community Education Department, Universitas Pendidikan Indonesia. Reasearcher in Literacy, parenting and community empowerment.

Ace Suryadi, Professor at Community Education Department, Universitas Pendidikan Indonesia. Researcher in Policy education and Economic. Education consultant at government agency.

Dadang Yunus Lutfiansyah, a Lecture at Community Education Department, Universitas Pendidikan Indonesia. Researcher in Empowering, Andragogy, Literacy and Community Education. 